19 Revue d'histoire du XIXe siècle

Société d'histoire de la révolution de 1848 et des

révolutions du XIXe siècle

$5 \mid 1989$

Histoires de centenaires, ou le devenir des révolutions

\title{
La commémoration de la Commune de Paris en
} Italie

\section{Renato Monteleone}

\section{OpenEdition}

\section{Journals}

Electronic version

URL: http://journals.openedition.org/rh19/42

DOI: $10.4000 /$ rh 19.42

ISSN: $1777-5329$

\section{Publisher}

La Société de 1848

\section{Printed version}

Date of publication: 1 June 1989

ISSN: 1265-1354

\section{Electronic reference}

Renato Monteleone, "La commémoration de la Commune de Paris en Italie », Revue d'histoire du XIXe siècle [Online], 5 | 1989, Online since 09 September 2008, connection on 02 May 2019. URL : http:// journals.openedition.org/rh19/42 ; DOI : 10.4000/rh19.42

This text was automatically generated on 2 May 2019.

Tous droits réservés 


\title{
La commémoration de la Commune de Paris en Italie
}

\author{
Renato Monteleone
}

\section{ABSTRACTS}

No abstract available by now

Pas de résumé disponible actuellement

INDEX

Mots-clés: Commémoration 